\title{
A Study of Safety Management in the Nigerian Construction Industry
}

\author{
Samuel Oladipo Olutuase \\ Department of Business Administration, Faculty of Management Sciences, University of Jos Jos, Plateau State, \\ Nigeria
}

\begin{abstract}
Given the hazardous nature of the construction industry world over, the need for an effective safety management system which aims at forestalling the risks and hazards inherent on site has been reiterated by recent studies and applicable laws. Studies however show that level of effectiveness differs from country to country; industry to industry and from company to company. This study therefore undertakes both qualitative and quantitative investigation into the safety management system of a Nigeria-based construction company with a view of determining how compliant the system is to international standards. Identifying five major components and fifteen elements in the study, both primary and secondary data were collected through personal interviews, structured questionnaire and observation and these were analysed using One Sample t-test at 0.05 level of significance. The results show that though a form safety management system exists in the company, the system is however poorly organised and consequently, it is characterised by ineffectiveness and poor documentation. It is therefore recommended that management gives an urgent attention to the company's safety management system with an intense interest to standardise its operations and functionality. As a roadmap to achieving this, the paper proposes an integrated "PCR" safety model based on the "TAB" philosophy.
\end{abstract}

Keywords: Safety Management System; Construction Industry, Risks, PCR-Model, Work sites, Hazards.

\section{Background}

The importance of providing safe workplace has been reiterated by various related studies because of the intrinsic hazard and risk factors that undoubtedly underlie every work situation and their negative impact on a company's overall performance. While risk is the chance or probability that a person will be harmed or experience an adverse health effect if exposed to a hazard, hazard on the other hand refers to the situation or source (which could be biological, chemical, physical or ergonomic) of potential damage to somebody, property or equipment. It is believed that some industries are more hazardous that some others. The construction industry world over, is however considered as one of the most hazardous industry. The International Training Centre of the International Labour Organisation (2011) claims that one in six fatal accidents at work occur on a construction site. It further stated that no less than 60,000 fatal accidents occur on construction sites around the world every year. Similar conclusions were made by Keller \& Keller, (2009) and Injuries Board (2009).

The fact that a construction job or work environment is considered as highly risky and hazardous does not mean that its susceptibility to accident is not controllable - this largely depends on "work situation" which is humanly controllable. Safety records in the same construction industry in most advanced countries have proven this to be true. Little wonder Koehn, Ahmed, and Jayanti (2000), Idoro (2008) and Enhassi, Choudhry, Mayer \& Shoman (2008) all express similar worry as to why worse safety conditions persist on construction work sites in most developing countries like Nigeria. The irony of the situation is that the causes of accidents are well known and almost all preventable and as other business issues, occupational safety and health (OSH) can be managed in the enterprise (The International Training Centre of the ILO, 2011; Indian Council of Medical Research, 2003) but the reality of it is contrary in practice.

Previous studies such as Bluff (2003); Needleman (2000); Saksvik \& Quinlan (2003); LaMontagne $e t$ al (2003); and Indian Council of Medical Research (2003) uniformly recommend that construction firms adopt safety system that seeks to prevent the occurrence of accidents rather than essentially managing accident cases and victims by paying medical bills and compensation. The core of such safety management system as highlighted by Bluff (2003) includes "systematic identification of hazards, assessment and control of risks, evaluation and review of risk control measures" to ensure that they are effectively implemented and maintained. Needleman (2000) on the other hand recommend that an effective safety system management requires management commitment to OHS; assignment of responsibilities; OHS procedures; OHS communication mechanisms; hazard identification, prevention and control; accident investigation; OHS training; documentation and evaluation of program effectiveness. Bluff (2003) further opined that if such safety management system would be effective then responsibility must be designated to competent safety personnel who will determine and implement the required preventive measures; that workers will actively be involved; and that procedures are documented and repeatable. This implies that an effective safety management system requires the 
implementation of core structures and processes and action by key players. Meanwhile, Indian Council of Medical Research (2003), Bluff (2003), Dorji \& Hadikusumo (2006) argued that a successful safety system should be policy-based. This implies that having a clearly stated safety policy is the starting point for developing and implementing a safety management system on the construction sites. The result then should be reduced accidents, injuries, sick pay, fatalities, lost work-hours, compensation claims, absenteeism, workers' agitation, overall costs of project; and significant improvement in efficiency and profitability (Awodele and Ayoola, 2005; Aksorn \& Hadikusumo, 2007; Enhassi, Choudhry, Mayer \& Shoman, 2008).

Nigerian construction firms especially the multinationals which seem to have inherited safety policies and systems from their parent companies still record repeated cases of accidents and injuries some of which include falls from height, trapped by something collapsing or overturning, struck by a moving vehicle, contact with electricity or electrical discharge, struck by flying/falling object during machine lifting of materials, contact with operating machinery or material being machined, exposure to hot or harmful substance or fire outbreak that engulfed their entire office premises (Consultnet Ltd, 2011). Most often, the problem is not the level of awareness of importance of safety neither is a safety policy absent but it is more related to poor or lack of implementation of safety programmes and systems, as it is with many other key players in the Nigerian construction industry (LaMontagne et al, 2003; Indian Council of Medical Research, 2003).

Procedures and programmes of safety management system of construction firms are naturally expected to lead to highly safe construction sites if they are well followed and implemented. Research studies however, claim that accident and injury rate in many developing countries such as Nigeria is considerably higher than in Europe, U.S. and Australia (Idoro, 2004 \& 2007). Koehn, Ahmed \& Jayanti (2000) in Bust, Gibb \& Pasquire (2004) reported that statistics has shown that there are 8 or 9 times as many fatalities and accidents on construction sites in developing countries than in industrialized developed regions. This is similar to the claims of Awodele \& Ayoola, (2005) and Smallwood \& Haupt (2005) that not less than hundreds of construction workers are being killed each year and many more rendered permanently disabled on Nigerian construction sites. It is either the installed safety management system is poorly managed or the safety system is not adequately addressing all the relevant safety issues involved in each construction project and site thereby making workers on site highly prone to accident. This study therefore found it necessary to assess performance level of installed safety management system existing in a typical Nigerian construction industry.

\section{Methodology}

This research adopted the case study approach, randomly drawing a sample of 111 staff members from a population of 244 management and junior staff members of a construction company in Nigeria. The researcher spent a period of 12 weeks in the office premises and at various work sites of the construction company. During this period, the researcher observed, explored safety records, interacted with workers at sites on safety issues, and administered questionnaires and also interviewed some management staff, all in the bid to evaluate the key elements, components, practices and coverage of safety system of the construction company and to particularly determine performance level of key elements as well as the major components of safety system.

\subsection{Variables of the Study}

On the basis of impressive safety system and records at companies like that of Barrick Gold Corporation (a leading mining company) (see figure 1), it can be assumed that with an appropriate Safety Management System and a conscientious implementation, there will lead to significant improvement in safety standards and performance of a construction company over time.

Figure 1: Employees and Contractors Combined Recordable Injury Frequency Rate at Barrick's sites, 2010.

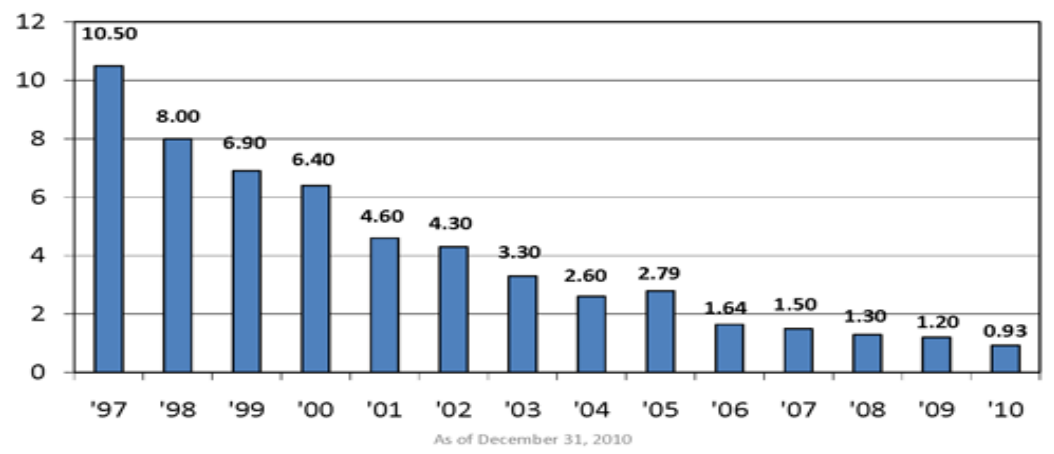

Source: Barrick Gold Corporation's website at http://www.barrick.com/Theme/Barrick/files/safetyhealth/safety-performance.png 
According to Consultnet (2011), an effective safety management system should include but not limited to the following key and major elements summarised in table 1 below.

Table 1: Major and Key Elements of a Construction Safety Management System

\begin{tabular}{|c|c|}
\hline Major Components & Key Elements \\
\hline \multirow{4}{*}{ CORPORATE SAFETY LEADERSHIP } & 1.1 Designation of Safety Responsibilities to Trained Personnel \\
\hline & 1.2 Direct Safety Talks with workers \\
\hline & 1.3 Adequate $\&$ Timely supply of PPEs \\
\hline & 1.4 Regular Safety Audit \\
\hline \multirow{2}{*}{ RISK MANAGEMENT } & 2.1 Systematic Hazard Identification \\
\hline & 2.2 Assessment of Risk Level \\
\hline \multirow{3}{*}{ SAFETY TRAINING } & 3.1 Safety orientation for new/transferred workers \\
\hline & 3.2 Pre-project safety trainings received \\
\hline & 3.3 Safety Trainings Received \\
\hline \multirow{3}{*}{ OPERATIONAL CONTROL } & 4.1 Scheduled in-house inspections \\
\hline & 4.2 Proper display of safety/ caution signs \\
\hline & 4.3 Resident Safety Officer at sites \\
\hline \multirow{3}{*}{ EFFECTIVE RESPONSE } & 5.1 Availability \& adequacy of clinical services \\
\hline & 5.2 Functional Fire Extinguishers \\
\hline & 5.3 Clarity of Emergency Exit \\
\hline
\end{tabular}

Source: Field Work, March 2012

\section{$1.2 \quad$ Research Hypotheses and Analytical Tools}

Three hypotheses are served as overall guide to the conduct of this research. They are:

One, $H_{o}$ : The individual performance level of key elements of safety system of a typical Construction Company in Nigeria does not measure up to minimum global performance benchmark.

Two, $H_{o}$ : The major components of safety system of a typical Construction Company in Nigeria do not measure up to minimum global performance benchmark.

Three, $H_{o}$ : The existing safety management system in a typical Construction Company in Nigeria is not effectively managed and well documented.

The quantitative data were collected were analysed using One Sample t-test at 0.05 level of significance, in order to arrive at the decision on whether to accept or reject null hypotheses. The decision not to reject the null is on the condition that the t-calculated is less than the t-tabulated at $95 \%$ confidence interval with 80 degree of freedom. This gives a t-calculated value of 1.99. Otherwise, the alternate hypotheses are accepted. On the other hand, qualitative data generated through observation and personal interview were transcribed and organized into emergent themes.

\section{Data Analysis And Discussion Of Findings}

Repeated visits were made by the researcher to selected sites where construction work was mostly at peak levels in order to personally administer questionnaires to a total of 81 workers on sites. This represents $72.98 \%$ of the original sample size. Alongside, observations were made and interviews conducted on personal and group basis. The questions all relate to the key elements of a typical safety management system in a construction firm. The outcome is presented in table 4 below.

\subsection{Workers' Rating Of Safety System And Test Of Hypotheses}

The analysis of the data generated by the questionnaire show how construction workers at a typical Nigerian construction company rate each individual element and major component of the Safety Management System of the company. This is shown in table 2 below. 
Table 2: Scoring of each element and major component of the Safety Management System at a Typical Nigerian Construction Company as rated by the workers on site

\begin{tabular}{|c|c|c|c|}
\hline $\begin{array}{c}\text { Major } \\
\text { Components }\end{array}$ & Key Elements & $\begin{array}{l}\text { Element } \\
\text { Score } \\
(\mathbf{1 0 0 \%})\end{array}$ & $\begin{array}{c}\text { Component } \\
\text { Average } \\
\text { Score } \\
(\mathbf{1 0 0 \% )} \\
\end{array}$ \\
\hline \multirow{4}{*}{$\begin{array}{l}\text { CORPORATE } \\
\text { SAFETY } \\
\text { LEADERSHIP }\end{array}$} & 1.1 Designation of Safety Responsibilities to Trained Personnel & 24.2 & \\
\hline & 1.2 Direct Safety Talks with workers & 30.62 & \\
\hline & 1.3 Adequate \& Timely supply of PPEs & 23.95 & \\
\hline & 1.4 Regular Safety Audit & 21.73 & \\
\hline & & TOTAL & 25.125 \\
\hline \multirow{2}{*}{$\begin{array}{l}\text { RISK } \\
\text { MANAGEMEN } \\
\text { T } \\
\end{array}$} & 2.1 Systematic Hazard Identification & 29.14 & \\
\hline & 2.2 Assessment of Risk Level & 29.38 & \\
\hline & & TOTAL & 29.26 \\
\hline \multirow{3}{*}{$\begin{array}{l}\text { SAFETY } \\
\text { TRAINING }\end{array}$} & 3.1 Safety orientation for new/transferred workers & 26.17 & \\
\hline & 3.2 Pre-project safety trainings received & 29.88 & \\
\hline & 3.3 Safety Trainings Received & 30.12 & \\
\hline & & TOTAL & 28.72 \\
\hline \multirow{3}{*}{$\begin{array}{l}\text { OPERATIONA } \\
\text { L CONTROL }\end{array}$} & 4.1 Scheduled in-house inspections & 34.07 & \\
\hline & 4.2 Proper display of safety/ caution signs & 34.57 & \\
\hline & 4.3 Resident Safety Officer at sites & 30.12 & \\
\hline & & TOTAL & 32.92 \\
\hline \multirow{3}{*}{$\begin{array}{l}\text { EFFECTIVE } \\
\text { RESPONSE }\end{array}$} & 5.1 Availability \& adequacy of clinical services & 73.83 & \\
\hline & 5.2 Functional Fire Extinguishers & 65.19 & \\
\hline & 5.3 Clarity of Emergency Exit & 38.52 & \\
\hline & & TOTAL & 59.18 \\
\hline
\end{tabular}

Source: Field Work, March 2012

The results of test of hypotheses for individual key elements, major components of and the overall performance of safety management system at a typical Nigerian Construction Company is given in tables $3 \mathrm{a}, 3 \mathrm{~b}$, $3 \mathrm{c}$, and $3 \mathrm{~d}$ below.

Table 3a: Summary of Results for Key Elements used to measure the Safety Management System of Typical Nigerian Construction Company

\begin{tabular}{|c|c|c|c|}
\hline Key Elements & $\begin{array}{l}\text { Calculated } \\
\text { Value of T }\end{array}$ & $\begin{array}{c}\text { Table Value } \\
\text { of T @ } 95 \% \\
\text { CI }\end{array}$ & DECSION \\
\hline \multicolumn{4}{|l|}{ CORPORATE SAFETY LEADERSHIP } \\
\hline 1.1 Designation of Safety Responsibilities to Trained Personnel & -24.584 & 1.99 & Do not Reject $H_{o}$ \\
\hline 1.2 Direct Safety Talks with workers & -10.960 & 1.99 & Do not Reject $H_{o}$ \\
\hline 1.3 Adequate \& Timely supply of PPEs & -34.877 & 1.99 & Do not Reject $H_{o}$ \\
\hline 1.4 Regular Safety Audit & -52.955 & 1.99 & Do not Reject $H_{o}$ \\
\hline \multicolumn{4}{|l|}{ RISK MANAGEMENT } \\
\hline 2.1 Systematic Hazard Identification & -15.676 & 1.99 & Do not Reject $H_{o}$ \\
\hline 2.2 Assessment of Risk Level & -16.688 & 1.99 & Do not Reject $H_{o}$ \\
\hline \multicolumn{4}{|l|}{$\begin{array}{l}\text { SAFETY TRAINING } \\
\end{array}$} \\
\hline 3.1 Safety orientation for new/transferred workers & -16.527 & 1.99 & Do not Reject $H_{o}$ \\
\hline 3.2 Pre-project safety trainings received & -12.240 & 1.99 & Do not Reject $H_{o}$ \\
\hline 3.3 Safety Trainings Received & -11.620 & 1.99 & Do not Reject $H_{o}$ \\
\hline \multicolumn{4}{|l|}{ OPERATIONAL CONTROL } \\
\hline 4.1 Scheduled in-house inspections & -7.790 & 1.99 & Do not Reject $H_{o}$ \\
\hline 4.2 Proper display of safety/ caution signs & -8.667 & 1.99 & Do not Reject $H_{o}$ \\
\hline 4.3 Resident Safety Officer at sites & -11.040 & 1.99 & Do not Reject $H_{o}$ \\
\hline \multicolumn{4}{|l|}{ EFFECTIVE RESPONSE } \\
\hline 5.1 Availability \& adequacy of clinical services & 5.757 & 1.99 & Reject $H_{o}$ \\
\hline 5.2 Functional Fire Extinguishers & 3.245 & 1.99 & Reject $H_{o}$ \\
\hline 5.3 Clarity of Emergency Exit & -5.698 & 1.99 & Do not Reject $H_{o}$ \\
\hline
\end{tabular}

Source: Data analysis of Field Survey (2012) 
Table 3b: Result for Major Components of measure the Safety Management System of a Typical Nigerian

Construction Company

\begin{tabular}{|l|r|r|l|}
\hline \multicolumn{1}{|c|}{ Major Components } & $\begin{array}{c}\text { Calculated Value } \\
\text { of T }\end{array}$ & $\begin{array}{c}\text { Table Value of T } \\
\text { @ 95\% CI }\end{array}$ & \multicolumn{1}{|c|}{ DECSION } \\
\hline Corporate Safety Leadership & -92.561 & 1.99 & Do not Reject $H_{o}$ \\
\hline Risk Management & -17.540 & 1.99 & Do not Reject $H_{o}$ \\
\hline Safety Training & -5.823 & 1.99 & Do not Reject $H_{o}$ \\
\hline Operational Control & -1.775 & 1.99 & Do not Reject $H_{o}$ \\
\hline Effective Response & 10.542 & 1.99 & Reject $H_{o}$ \\
\hline
\end{tabular}

Source: Data analysis of Field Survey (2012)

Table 3c: Result for overall safety management performance of a Typical Nigerian Construction Company

\begin{tabular}{|l|c|c|c|}
\hline & $\begin{array}{c}\text { Calculated } \\
\text { Value of T }\end{array}$ & $\begin{array}{c}\text { Table Value of T @ } \\
\mathbf{9 5 \%} \mathbf{C I}\end{array}$ & DECSION \\
\hline Overall Safety Management Performance & -3.240 & 1.99 & Do not Reject $H_{o}$ \\
\hline
\end{tabular}

Source: Data analysis of Field Survey (2012)

Table 3d: Workers Position on Safety Training they received at a typical Nigerian construction company

\begin{tabular}{|l|c|c|}
\hline \multicolumn{1}{|c|}{ RESPONSES } & No. of RESPONDENTS & \% of Respondents \\
\hline Strongly Disagree & 14 & 17.284 \\
\hline Disagree & 8 & 9.8765 \\
\hline Undecided & 14 & 17.284 \\
\hline Agreed & 28 & 34.568 \\
\hline Strongly Agree & 16 & 19.753 \\
\hline Missing & 1 & 1.2346 \\
\hline TOTAL & $\mathbf{8 1}$ & $\mathbf{1 0 0}$ \\
\hline
\end{tabular}

Source: Data analysis of Field Survey (2012

Table 4: Summary of Responses to Interview Questions and Observations made during visits to a Nigerian Construction Firm's Work sites (Feb - Mar, 2012).

\begin{tabular}{|c|c|c|}
\hline ELEMENTS & INTERVIEWS & OBSERVATIONS \\
\hline $\begin{array}{l}\text { Provision of } \\
\text { PPEs }\end{array}$ & $\begin{array}{l}\text { The Area Office would normally wait } \\
\text { for consignment from the Head Office before } \\
\text { they make PPEs available to workers. } \\
2 \text { PPEs until they are employed on permanent basis. } \\
\text { P. It sometimes takes up to six months } \\
\text { for some workers to get their PPEs. } \\
4 \text { Some workers had to source PPEs } \\
\text { from other sources like buying, from colleagues, } \\
\text { etc }\end{array}$ & $\begin{array}{l}\text { The latest safety boots provided } \\
\text { in March } 2012 \text { as at the time of the study did } \\
\text { not cover the ankle like the previous } \\
\text { supplies. } \\
\text { 2. A welder complained that the } \\
\text { welders' goggles provided are too heavy. }\end{array}$ \\
\hline $\begin{array}{l}\text { Safety } \\
\text { Organisation }\end{array}$ & $\begin{array}{l}\text { 1. Resident safety officers were just } \\
\text { employed in February 2012. } \\
2 . \quad \text { The Safety Officer at one of the sites } \\
\text { interviewed does not have relevant training that } \\
\text { fits him to the job. }\end{array}$ & $\begin{array}{l}\text { There is no safety executive in the } \\
\text { management hierarchy to take a company- } \\
\text { wide oversight of safety management. } \\
2 \text {. No safety representative is on } \\
\text { board whenever a project is being designed. }\end{array}$ \\
\hline $\begin{array}{l}\text { Documentation } \\
\text { and } \\
\text { Investigation }\end{array}$ & $\begin{array}{l}\text { 1. Company keeps records of reported } \\
\text { accidents and compensations paid. } \\
2 . \quad \text { A preliminary investigation is done } \\
\text { and documented on each accident report. }\end{array}$ & $\begin{array}{l}\text { 1. No further investigation is } \\
\text { documented on accidents reported. } \\
2 . \quad \text { A documented procedure for } \\
\text { identifying applicable regulatory } \\
\text { requirements is not established. }\end{array}$ \\
\hline $\begin{array}{l}\text { Performance } \\
\text { Measurement }\end{array}$ & & $\begin{array}{l}\text { Rate of accidents, lost time, compensation } \\
\text { paid, and further analysis to measure safety } \\
\text { management system for each finished } \\
\text { project, or year is not documented for future } \\
\text { review. }\end{array}$ \\
\hline $\begin{array}{l}\text { Contractors' } \\
\text { Staff }\end{array}$ & $\begin{array}{l}\text { No contractors' staff members were interviewed } \\
\text { because they were not within the scope of the } \\
\text { study. }\end{array}$ & $\begin{array}{l}\text { However a particular attention was paid to } \\
\text { about contractors' staff } 100 \text { workers on } \\
\text { different sites. It was observed that majority } \\
\text { do not put on Safety wears while on site. } \\
\text { And their presence on site could impact on } \\
\text { the safety management system of the } \\
\text { company. }\end{array}$ \\
\hline Safety Display & Workers at the fuel bank would appreciate if & Safety notices such as "KEEP OFF", \\
\hline
\end{tabular}




\begin{tabular}{|c|c|c|}
\hline & $\begin{array}{l}\text { notices like "KEEP OFF, HIGHLY } \\
\text { INFLAMABLE AREA" hang around their work } \\
\text { area. }\end{array}$ & $\begin{array}{l}\text { "REMEMBER TO SWITCH OFF", } \\
\text { "INCASE OF EMERGENCY..." were not } \\
\text { prominently displayed around potentially } \\
\text { risky work areas either to non-workers or } \\
\text { workers not in those units }\end{array}$ \\
\hline $\begin{array}{l}\text { Ambulance/ } \\
\text { Stretcher }\end{array}$ & $\begin{array}{l}\text { Interviews show that there is no Ambulance } \\
\text { stationed at Quarry site, and other sites. Although } \\
\text { Quarry had a vehicle it uses in lieu. }\end{array}$ & $\begin{array}{l}\text { The Quarry site at Vom is affiliated to Vom } \\
\text { Christian Hospital for accident cases beyond } \\
\text { the base clinic. The hospital is located at } \\
\text { about } 5 \mathrm{~km} \text { from the site. There is good } \\
\text { access road and communication facilities }\end{array}$ \\
\hline Safety Manual & $\begin{array}{l}\text { 1. } 98 \% \text { of workers interviewed affirmed } \\
\text { that they do not about the company's Safety } \\
\text { Manual. } \\
2 . \\
\text { know about it affirmed that they do not have } \\
\text { access to it }\end{array}$ & $\begin{array}{l}\text { The Safety Manual is not Company-specific. } \\
\text { That is, it does not specify safety philosophy, } \\
\text { objectives and goals which are publicised } \\
\text { throughout the company, etc }\end{array}$ \\
\hline $\begin{array}{l}\text { Enforcement of } \\
\text { Safety Rules }\end{array}$ & $\begin{array}{l}\text { There is only one common feature of safety } \\
\text { enforcement on sites and that is the using of } \\
\text { safety kits (only when the company has just } \\
\text { provided them). }\end{array}$ & $\begin{array}{l}\text { As observed, it is the executive } \\
\text { members of the workers' union that assume } \\
\text { the responsibility of enforcing the use of } \\
\text { safety wears. } \\
2 \text {. Foremen and supervisors also do } \\
\text { the same but that amidst their tight work } \\
\text { schedule. }\end{array}$ \\
\hline Training & $\begin{array}{l}\text { 1. A worker claimed he attended fire } \\
\text { service training along with three other workers } \\
\text { only once in } 2008 \text {. } \\
2 . \quad \text { The company sponsors only about } 4 \\
\text { workers for similar training annually. }\end{array}$ & $\begin{array}{l}\text { 1. The percentage of trained workers } \\
\text { is quite insignificant. } \\
2 . \quad \text { The training system is not result- } \\
\text { oriented as it does not evaluate the impact on } \\
\text { the safety system. }\end{array}$ \\
\hline
\end{tabular}

Source: Field Work, March 2012

\subsection{Discussion Of Findings}

Fifteen key elements expected of a typically effective Safety Management System were selected and grouped into five major components for analysis. The results presented in tables $2-4$ however, supported the three major hypotheses earlier stated in section 2.3 thus implying that the Safety Management System in practice at a typical Nigerian Construction sites statistically measures below acceptable standard.

\section{Corporate Safety Leadership}

Successful implementation of a Safety Management System, according to the Government of Alberta (2012) requires amongst other factors, management commitment to the system and effective allocation of resources. Robotham (2012) maintains the same position and further added that companies with high profile Safety Management Systems are usually those that have their senior and middle management demonstrate clear and high profile commitment to safety, spending over 30\% of their time directly on OHS issues. This is what Barrick Gold Corporation (2010) calls Corporate Safety Leadership which should, but not limited to these, include: designation of safety responsibilities to trained personnel, direct safety talks with workers, adequate and timely supply of personal protective equipments, and regular safety audits. From the one-sample t-test conducted, the results show a t-value of $\mathbf{- 2 4 . 5 8 4}$ for element 1.1: designation of safety responsibilities to trained personnel; -10.960; element 1.2: direct safety talks with workers; - $\mathbf{3 4 . 8 7 7}$ for element 1.3: adequate and timely supply of personal protective equipments; and $\mathbf{- 5 2 . 9 5 5}$ for element1.4: regular safety audits by management. All of these fall below the critical value of 1.99 , thus implying that the senior and middle management of a typical construction company in Nigeria does not demonstrate a high level commitment to safety of workers and operations which meets global acceptable standards.

It is discovered at about the time of the study that the company had, in response to long time agitation of union leaders, engaged "untrained", "unprofessional" and "inexperienced" safety officers whose educational trainings were not more than secondary school level. This is far below the standard requirement for a safety officer. On the other hand, senior management and engineers who are expected to provide oversight safety functions throughout construction sites demonstrate low safety leadership except for fear of accident occurrence or until probably there is an incidence.

Besides, it was discovered that the company does not adequately and timely supply of personal protective equipments. Inadequate and untimely supply may be due to either low investment in safety wares or poor inventory management of safety kits. The idea of not supplying casual workers any personal protective equipment (as noted during interviews with some workers) simply reflects that management's view on and approach to safety is not comprehensive. The same factor may also explain the reason why management of a typical construction company in Nigeria practically show little or no concern when 100 workers under different contractors' staff would not put safety wears while being indirectly engaged on their work sites, ignoring the fact that their presence on site could impact on the safety management system of the company. Some workers 
who know about the standard quality of safety kits still complain about the quality of PPEs supplies. There is no medium that allows workers make suggestion on the make and quality of PPEs.

\section{Risk Management}

Risk management which involves hazard identification and risk assessment and control, is a major component of an effective Safety Management System. The results of data analysis on a typical construction company in Nigeria turned out t-values for element 2.1: Systematic Hazard Identification and 2.2: Assessment of Risk Level as -15.676 and -16.688 respectively. These again fall below the critical region of expected t-value of 1.99. It therefore implies that the current Safety Management System in practice at a typical Nigerian construction company is not adequately identifying all conceivable risk factors and hazards in the general work process or peculiar construction projects until when incidences have occurred. Similarly, it can be presumed that as long as potential hazards are not pre-identified, there is no way associated risk level can be evaluated, thus making project designs or work designs at a typical Nigerian construction company lack practicable preventive plans incorporated in them.

\section{Safety Training}

One other major component that should be part of a high-profile Safety Management System is safetyfocused training. In analysing this major component, the study identified three key elements viz: 3.1 Safety orientation for new/transferred workers; 3.2 Pre-project safety trainings received; and 3.3 Safety Trainings Received these turned out the following respective t-values: -16.527, -12.240 and -11.620. Again, all these indicate a poor performance level at a typical Nigerian construction company. Moreover, interviews with workers show that more than $70 \%$ (see table 3d) of the sampled workers do not receive safety training at a typical Nigerian construction company. One worker recalled that only four of them were sent to undertake fire service training in 2008 and another set of four workers in 2009. This is quite insignificant when compared to a total workforce that can be as high as 500 during peak periods. The reason for all these may be due to the obvious lack of appreciation for practical safety management system in the company.

\section{Operational Control}

Operational control is a Safety Management System component that borders much on implementation of safety strategies and tactics. This study focused on three key operational control elements viz: Scheduled inhouse inspections; Proper display of safety/ caution signs; and Resident Safety Officer at sites and the results show t-values of $-7.790,-8.667$ and -11.040 respectively. Whereas a regular monitoring and accountability are necessary to ensure effective operational control (Barrick Gold Corporation, 2010), a typical Nigerian construction company measures below the critical t-value of 1.99 on Scheduled in-house inspections; Proper display of safety/ caution signs; and Resident Safety Officer at sites. During site walk-around of this study, it was observed that supervisors and project managers moved round the site to monitor work progress but it was obvious that they hardly had an eye on safety. Particular notice was made that Management only remembers to ensures "things" are in order mostly when they get notice of inspection from the Ministry of Labour and Productivity in order to avoid sanctions or bad image. Similarly, there are hardly safety notices around work sites especially at Quarry, site offices and main yard while safety officers are only employed for some sites in February, 2012. All these may be due to poor risk management since operational controls and procedures that must be put in place to ensure safe construction work is directly determined by effective risk management.

\section{Effective Response}

Even though an effective Safety Management System is a proactive approach that seeks to prevent or mitigate the occurrence of accidents, injuries and incidences, yet the best of Safety Management Systems according to the Government of Alberta (2010) is said to lack a guarantee against certain natural disasters like earthquake and explosions which can spell grave consequences on operational safety, thus the need to incorporate a well thought-out Emergency Response Plan (ERP) into the overall Safety system. Three key elements were identified and measured. They are: Availability \& adequacy of clinical services; Functional Fire Extinguishers; and Clarity of Emergency Exit. The results show that performance level of two the three key elements (Availability \& adequacy of clinical services; and Functional Fire Extinguishers) exceeded the minimum standards with t-values of 5.757 and 3.245 respectively, both are greater than the critical value of 1.99. These results are also supported by the observation of good clinics at Quarry site and Main yard, where activities are always on-going. Besides, the Quarry site is affiliated to a hospital for accident cases that would be beyond the base clinic. The hospital is located at about $5 \mathrm{~km}$ from the site with good access road and communication facilities. Responses from over $54 \%$ of workers personally interviewed also indicate that the fire extinguishers are functional and regularly serviced/ replaced. This may be as a result of periodic inspection by Fire Services to the sites and the avoidance of sanctions. However, it was observed at the time of the study that 
there is no Ambulance for emergency stationed at Quarry site, three other sites where works were at peak although Quarry site had a vehicle it uses in lieu. Throughout all the site offices including the Quarry site, there are no marked spots as emergency exit for all within the site in case of any incidence. This is necessary as certain incidences may not be totally mitigated by even the best of Safety Management System.

\section{Recommending The Integrated "Pcr" Safety Model}

Based on the findings of the study, it is necessary for the management of a typical Nigerian construction company to give an urgent attention to their safety management system with an intense interest to standardise its operations and functionality. The integrated "PCR" safety model, based on the "TAB" philosophy is thus recommended to drive construction safety performance upward. In brief, the model suggests, as illustrated in figure 2 below, that the entire work process must totally an systematically fused/integrated into the safety management system and vice versa.

Figure 2: Illustrating the converse integration of work process into the safety management system

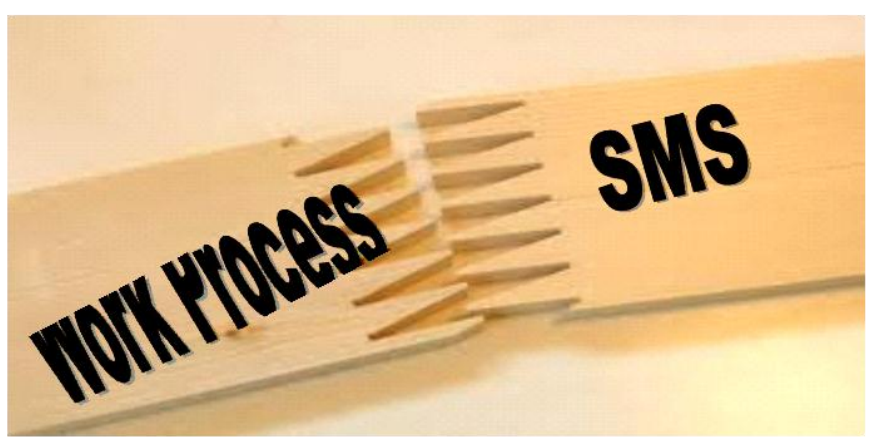

\subsection{Explaining the INTEGRATED "PCR" SAFETY MODEL}

The integrated "PCR" safety model exhibits four critical features, three of which form the acronym "PCR". They are: Integrated, Proactive, Control and Reactive.

a. Integrated: it is strongly recommended that safety management system be fitly integrated into the entire work process of a typical Nigerian construction company spanning project planning to delivery stages. This implies relevant safety measures are factored into project planning, job design and overall contractual agreement before construction activities would commence. Further, the fused system should take input from all relevant stakeholders to construction business: client, workers, management, safety professionals, host community and sub contractors. This way, a comprehensive safety system to which all construction stakeholders would intrinsically identify with would be derived and enforced.

b. Proactive: every good safety model must incorporate proactive measures which at the minimum should include: risk management and safety training. Risk management involves systematic identification of potential hazards on construction sites at the design stage; analysing the risk level of each hazard identified, and then determining what appropriate preventive safety plan/measures to initiate and incorporate into the entire work process. Furthermore, safety training should be organised in response to risk management outcome. And this should form the bedrock of training and retraining of new, transferred and/or re-shuffled workers prior commencement of construction activities. Training, which can be in-house or outsourced, should be resultoriented by conducting post training evaluation from time to time until safety behaviour seems permanent and core safety lessons are learned.

c. Control: in consultation with safety experts, a typical construction company should set up an internal and independent Safety Unit employing well qualified, certified and experienced safety professional, designated with company-wide safety responsibilities. Apart from formulating, reviewing, recommending changes to safety policies and strategies as well as executing all other typical safety functions, this Unit will in conjunction with managers at all levels, conduct conscientious operational control by way of paying scheduled and purposeful visits in their operational routine. This will assure effective monitoring of safety practices and implementation processes.

d. Reactive: exigencies are inevitable. Though good safety management system is expected to guarantee maximum safety, some natural disasters like earthquakes may be inevitable. The model incorporates reactive measures that will ensure effective response to arresting unpleasant events as they occur around work sites. Some of these measures include provision of high quality clinic services, fire-extinguishers, clearly marked and paved emergency exits, caution signs, rescue vans and gadgets, alarm bells, etc. With this, consequences of incidences could be reduced from either fatal or severe to "minor". 


\section{6}

\section{The "TAB" philosophy}

Underlying the integrated "PCR" safety model is a safety philosophy called "Think-Act-Be" (TAB). Risk management, a typical proactive function carried out at the planning stage requires "THINKING". So then, the safety culture within the Nigerian construction industry should be: Before starting construction project, think about the possible dangers; before executing any construction job role as an individual, think about the possible dangers. It is when the possible dangers are well thought out that one can ACT in a manner that would assures safety. Then the human as well as property elements within the system can BE safe!

In other words, it is when THINK ABOUT SAFETY that you can more probably ACT SAFELY so that you and everyone connected to your job, directly or indirectly, would BE SAFE. Put in another way, SAFETY consciousness will lead to SAFETY compliance which will in turn lead to SAFETY coverage. This sort of philosophy will positively and collectively impact the attitude of everyone in the company towards good safety practices; generate and reinvigorate a strong safety culture throughout the company and consequently drive continuous improvement in the safety management system of a typical construction company, not only in Nigeria but world over.

Figure 3: Integrated Proactive Control and Reactive (PCR) Safety Model For Typical Construction Company

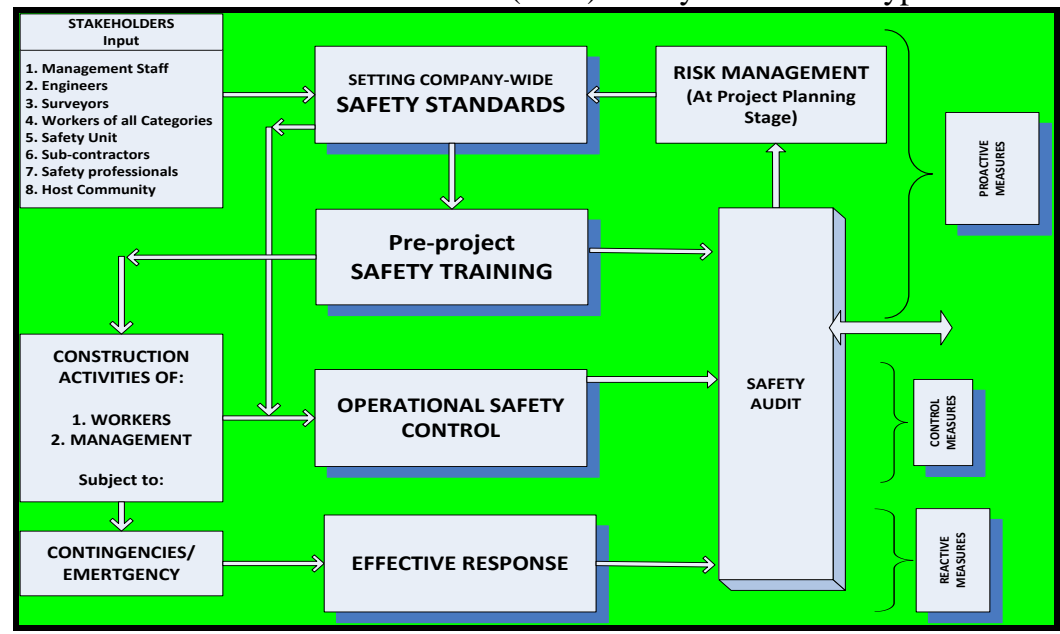

\section{Conclusion}

Providing "safe" workplace requires a proactive, precautionary approach that seeks to eliminate all risk factors inherent in a job or at least ameliorate the impact of their occurrence on. This approach is wrapped up in the term "Safety Management System. A typically effective safety management system should encapsulate the actions managers at all levels take in order to create an organisational setting in which workers will be trained and motivated to perform safe and productive construction jobs. Amongst other things, this system must include Designation of Safety Responsibilities to Trained Personnel; Direct Safety Talks with workers; Adequate \& Timely supply of PPEs; Regular Safety Audit; Systematic Hazard Identification; Assessment of Risk Level; Safety orientation for new/transferred workers; Pre-project safety trainings received; Safety Trainings Received; Scheduled in-house inspections; Proper display of safety/ caution signs; Resident Safety Officer at sites; Availability \& adequacy of clinical services; Functional Fire Extinguishers; and Clarity of Emergency Exit. All these must be well articulated into a perfect whole that is fitly integrated into the entire work process company-wide. Implementation must be effectively executed and closely monitored by Safety Unit. Furthermore, safety performance expectations must be in line with best global practices, international conventions, national and industry applicable requirements and local laws for a safety management system to be rated above benchmark

\section{References}

[1] Aksorn, T \& Hadikusumo, B.H.W. (2007). Gap Analysis Approach for Construction Safety Program Improvement. Journal of Construction in Developing Countries, 12(1): 77 - 97

[2] Barrick Gold Corporation (2010). Safety and Health Management System Policy. Retrieved from http://www.barrick.com/Theme/Barrick/files/safety-health/Safet-and-Health-Policy.pdf

[3] Barrick Gold Corporation (2010). Annual Report. Retrieved from http://www.barrick.com/Theme/Barrick/files/safety-health/safetyperformance.png

[4] Barrick Gold Corporation (2010). Annual Report: Strong Focus on Responsible Mining, pp 23- 28. Retrieved from http://www.barrick.com/theme/barrick/files/annual-report-2010/PDF/11-Strong-Focus-on-Responsible-Mining.pdf

[5] Awodele, O.A. \& Ayoola, M.C. (2005). An Assessment of Safety Programmes on Construction Sites. Journal of Land Use and Development Studies, 1(1). Retrieved from 
http://journalanduse.org/Assets/Vol1\%20papers/AN\%20ASSESSMENT\%20OF\%20SAFETY\%20PROGRAMMES\%20ON\%20C ONSTRUCTION\%20SITES.pdf

[6] Bluff, L. (2003). Systematic Management of Occupational Health and Safety. Being a Working

[7] Paper 20 for the National Research Centre for Occupational Health and Safety Regulation. Canberra ACT: Australian National University. Retrieved from http://dspace.anu.edu.au/bitstream/1885/39967/2/OHSMS.wp20.pdf

[8] Bust, P. D., Gibb, A. G. \& Pasquire, C. L. (2004). Health and safety on global

[9] Projects in Developing Countries - Towards good practice. Proceedings of International Symposium on Globalisation and Construction AIT Conference Centre, Bangkok, Thailand 17-19 November, 2004:pp.135 - 142.

[10] Consultnet Ltd (2011). Construction Site Safety (slide presentation). Retrieved from http://www.consultnet.ie/Construction\%20Site\%20Safety.ppt
Dorji, K. \& Hadikusumo, B.H.W. (2006). Safety Management Practices in the BhutaneseConstruction Industry. Journal of

[11] Dorji, K. \& Hadikusumo, B.H.W. (2006). Safety Management Practices in the BhutaneseConstruction Industry. Journal of
Construction http://web.usm.my/jcdc/input/JCDC\%20VOL\%2011(2)/4_Kin\%20Dorji\%20(p.53-75).pdf

[12] Enhassi, A., Choudhry, R.M., Mayer, P.E., \& Shoman, Y. (2008). Safety Performance of

[13] Subcontractors in the Palestinian Construction Industry. Journal of Construction in Developing Countries, $13(1)$, 51 - 62

[14] Government of Alberta (2012). Building an Effective Health and Safety Management System. Retrieved from http://employment.alberta.ca/documents/WHS/WHS-PS-building.pdf

[15] Idoro, G. I. (2004). The effect of globalization on safety in the construction industry in Nigeria, in

[16] Proceedings of International Symposium on Globalization and Construction, November, School of Civil Engineering, Asian Institute of Technology, Bagdok, Thailand.

[17] Idoro, G.I. (2007). Contractors' Characteristics and Health and Safety Performance in the Nigerian

[18] Construction Industry, in Proceedings of CIB World Building Conference on Construction for Development, Cape Town, South Africa, May, 14-18. Retrieved from http://www.irbdirekt.de/daten/iconda/CIB5293.pdf

[19] Idoro, G.I. (2008). Health and Safety Management Efforts as Correlates of Performance in the

[20] Nigerian Construction Industry. Journal of Civil Engineering and Management, 14(4), 277-285. Retrieved from https://info.vgtu.lt/upload/civil_zurn/277-285-jcem-2008-4-idoro.pdf

[21] Indian Council of Medical Research (2003). A National Priority on Occupational Health and Safety Management System. Bulletin, Vol. 33, New Delhi, India: Shri J.N. Mathur

[22] Injuries Board (2009). Construction Safety Information. Retrieved from http://wiki.injuryboard.com/topic/constructionindustry.aspx

[23] International Training Centre of the ILO (2011). Occupational safety and health management in the construction sector. Retrieved from http://socialprotection.itcilo.org/en/courses/Open_courses/A904155

[24] Keller, S. J. \& Keller, J. R. (2009). Construction Accidents Statistics. Retrieved from http://www.2keller.com/library/constructionaccident-statistics.cfm

[25] Koehn, E., Ahmed, S. A., and Jayanti, S. (2000) Variation in construction productivity: developing countries. AACE International Transactions, Morgantown, (14)

[26] LaMontagne, A. D., Barbeau, E, Youngstrom, R. A., Lewiton, M., Stoddard, A.M., McLellan, D., Wallace, L.M. \& Sorensen G. (2004). Assessing and intervening on OSH programmes: effectiveness evaluation of the Wellworks-2 intervention in 15 manufacturing worksites. Occup Environ Med 61:651-660.

[27] Needleman, C. (2000). OSHA at the crossroads: conflicting frameworks for regulating OHS in the US.Retrieved from http://newcatalogue.library.unisa.edu.au/vufind/Record/738930

[28] Robotham, F. G. (2012). The 15 Most Important Components of an Effective Safety Management System. etrieved from http://www.ohschange.com.au/articles/The 15 Most_Important_Components of an_Effective Safety Management System/The 15 Most Important Components of an Effective Safety Management System.html Saksvik, P \& Quinlan, M. (2003). Regulating Systematic Occupational Health and Safety

[29] Management Comparing the Norwegian and Australian Experience. Industrial Relations, $58(1): 33$ - 59

[30] Smallwood, J. \& Haupt, T. (2005). The need for construction health and safety (H\&S) and the Construction Regulations: Engineers' perceptions. Journal of the South African Institution of Civil Engineering, 47(2): 2-8. Retrieved from http://www.saice.org.za/Portals/0/pdf/journal/vol47-2-2005/vol47_n2_a.pdf 